Prace Literackie LVI

Wrocław 2016

DOI: $10.19195 / 0079-4767.56 .4$

EWELINA GIŻKA

Katolicki Uniwersytet Lubelski Jana Pawła II

\title{
Motywy maryjne w twórczości Zygmunta Szczęsnego Felińskiego
}

W dziejach narodu polskiego kult Matki Boskiej od najdawniejszych wieków odgrywa istotną rolę. Ku Jej czci wznoszono wspaniałe świątynie (kościół Najświętszej Marii Panny w Krakowie, którego budowę rozpoczęto już w XIII wieku), a także zwykłe, przydrożne kapliczki, będące pięknym wyrazem wielkiej religijności prostego ludu. Opiece Maryi oddawano katedry (w Płocku, we Włocławku), opactwa i kolegiaty (w Łęczycy, Opatowie, Sandomierzu, Kaliszu) ${ }^{1}$. O wstawiennictwo u Syna, wsparcie prosili Ją przedstawiciele wszelkich stanów. Do Rodzicielki Jezusa zawsze kierowano gorące modlitwy w okresach pokoju, jak również w trudnych i dramatycznych momentach historii państwa polskiego (wojny, kolejne krwawe, kończące się klęskami i wzmożonymi represjami powstania, niewola narodowa).

Pobożność maryjna obecna w codziennym życiu Polaków wywarła ogromny wpływ na twórczość wielu pisarzy poszczególnych epok. W literaturze polskiej utwory sławiące Matkę Boską, posiadające analogiczny schemat kompozycyjny opierający się na ,zwrocie i prośbie"2, odnajdujemy już w poetyckiej spuściźnie średniowiecza. Któż nie zna bowiem słów Bogurodzicy czy Lamentu świętokrzyskiego będącego ,przepełnionym żalem, bólem, bezsilnością, zawiedzionymi nadziejami monologiem Najświętszej Marii Panny, ujawniającej swe doznania w obliczu Syna umęczonego na Golgocie"3. Zainteresowanie poetów postacią Matki Boskiej obserwujemy również w wieku XVII, z tą jednakże różnicą, iż w przeciwieństwie do wcześniejszego okresu wysuwającego Maryję na pierwszy plan, barok pokazuje Ją przez pryzmat stosunku do Chrystusa ${ }^{4}$. W tym duchu, jak

${ }^{1}$ Zob. S. Sawicki, Matka Boska w poezji średniowiecza i renesansu, [w:] Matka Boska w poezji polskiej, t. 1. Szkice o dziejach motywu, oprac. M. Jasińska et al., Lublin 1959, s. 9.

2 S. Nieznanowski, Średniowieczna liryka religijna. Rekonesans badawczy, [w:] Polska liryka religijna, red. S. Sawicki, P. Nowaczyński, Lublin 1983, s. 22.

3 Zob. T. Witczak, Literatura średniowiecza, Warszawa 1997, s. 133.

${ }^{4}$ K. Bukowski, Biblia a literatura polska. Antologia, Poznań 2003, s. 208. 
podaje Kazimierz Bukowski, tworzy Maciej Kazimierz Sarbiewski ${ }^{5}$. Motywy maryjne niezwykle rzadko pojawiające się u pisarzy XVIII wieku (poezja konfederacji barskiej, twórczość Konstancji Benisławskiej, Józefa Baki, Józefa Andrzeja Załuskiego, Franciszka Karpińskiego ${ }^{6}$ na nowo powracają w twórczości romantyków (Adam Mickiewicz, Teofil Lenartowicz, Bohdan Zaleski, Kornel Ujejski, Juliusz Słowacki, Cyprian Kamil Norwid, Zygmunt Krasiński), co według Antoniego Bednarka jest efektem: ówczesnych rozległych związków literatury z religią, refleksji teologicznej, trendów filozoficznych preferujących intuicyjne poznanie, wizji świata opartej na tajemnicy istnienia, aspektów kulturowych, do których autor zalicza ogólne zainteresowanie Biblią, sferą zjawisk nadprzyrodzonych ${ }^{7}$. W okresie „poromantycznym” dominuje wizerunek Matki Boskiej jako Królowej Polski: hetmanki i opiekunki (Maria Konopnicka, Wiktor Gomulicki, Bronisława Ostrowska) $)^{8}$. Natomiast w dwudziestoleciu międzywojennym ów wątek patriotyczny znika i ponownie odradza się w liryce okupacyjnej ${ }^{9}$.

Pisarzem nieco zapomnianym, w którego utworach czytelnik $\mathrm{z}$ łatwością dostrzega pojawiające się różne motywy maryjne (wierszowany żywot Matki Boskiej, cudowna obrona Poczajowa, malarz tworzący wizerunek Maryi, obrazy i kwiaty Jej poświęcone, modlitwy, pochwała miesiąca maja, lirnik głoszący cześć Bogarodzicy, Królowa Polski) jest Zygmunt Szczęsny Feliński (1822-1895) arcybiskup warszawski, przyjaciel Juliusza Słowackiego, uczestnik powstania wielkopolskiego (1848), profesor Akademii Duchownej w Petersburgu, wielki patriota, święty Kościoła katolickiego (kanonizowany przez Benedykta XVI w 2009 roku), pisarz religijny, wielki czciciel Najświętszej Maryi Panny.

Feliński w wierszu zatytułowanym Prośba o natchnienie bardzo precyzyjnie określił cele swojej twórczości literackiej, sygnalizując jednocześnie jej przynależność do nurtu maryjnego. Wspomniany liryk, będący swoistym programem poetyckim autora, rozpoczyna patetyczna apostrofa skierowana do Maryi:

Niepokalana Panienko Święta,

Którą Aniołów chór wielbi w niebie,

Oto ma dusza, czcią Twą przejęta,

Pragnie na ziemi uwielbiać Ciebie ${ }^{10}$.

5 Ibidem.

${ }^{6}$ R. Doktór, Wizerunek Matki Boskiej w poezji polskiej XVIII wieku, [w:] Literatura. Historia. Dziedzictwo. Prace ofiarowane profesor Teresie Kostkiewiczowej, red. T. Chachulski, A. Grześkowiak-Krwawicz, Warszawa 2006, s. 295-307.

7 A. Bednarek, Maryja w literaturze polskiej. Romantyzm, [w:] Encyklopedia katolicka, t. 12, Lublin 2008, s. 72-73.

8 Zob. M. Jasińska, Matka Boska w poezji poromantycznej (do r. 1918), [w:] Matka Boska w poezji polskiej, t. 1, s. 119-125.

9 M. Cybulski, Zygmunt Szczęsny Feliński - pisarz i człowiek, Warszawa 2015, s. 379.

10 Z.Sz. Feliński, Prośba o natchnienie, „Biesiada Literacka” 1902, nr 21, s. 406. Ten sam wiersz pod tytułem Wezwanie rozpoczyna Nowy wianuszek majowy z tajemnic życia Maryi przez arcybiskupa Szczęsnego Felińskiego na Jej cześć uwity, Lwów 1906, s. 1-2. 
Podmiot liryczny-poeta pragnący głosić chwałę Matki Boskiej na ziemi, w opozycji do wielbiących Ją chórów anielskich w niebie, następnie prosi swoją muzę i opiekunkę o obdarowanie go „,iskrą natchnienia”:

Do stóp Twych przeto kornie przypadam,

Nim na cześć Twoją rozpocznę pienie,

U tronu Twego serce me składam,

Racz tchnąć w nie, Pani, święte natchnienie ${ }^{11}$.

Feliński, przedstawiając Maryję, nazywaną w kolejnych wersach: „Panienką Świętą, Matką łaskawą, Najświętszą Bogarodzicą”, jako ,ofiarodawczynię talentu poetyckiego", wyraźnie inspiruje się tradycją baroku. Otóż, jak dowodzi Stefan Nieznanowski, wizerunek Najświętszej Panny zsyłającej dar słowa, pomagającej szczególnie tym, którzy chcą pisać na Jej cześć, jest popularnym motywem występującym w literaturze XVII wieku ${ }^{12}$. Dla przykładu w Obleżeniu Jasnej Gory Częstochowskiej Walentego Odymalskiego czytamy:

Panno, wspomóż mię, a przez szafirowe

Niebo, gdzie gwiazdy świecą Empirowe,

Obróć z wysoka na mnie oczy swoje

I wlej dar łaski w miałkie piersi moje ${ }^{13}$,

natomiast u Wespazjana Kochowskiego w Ofiarowaniu poesim polskiej Naświętszej Pannie Maryjej odnajdujemy następujące wyznanie: „Tyś dała słowa, o Matko, lichocie!/ Przez Cię i pióro w piśmiennej robocie" ${ }^{\text {14 }}$.

Podmiot liryczny Prośby o natchnienie porównujący się do ,nędznego, małego robaka, zdolnego jedynie pełzać po ziemi" z pokorą wierzy, że tylko przy pomocy Maryi ,wzleci w niebo skrzydły orlemi" ${ }^{15}$. To zestawienie wzniosłego nastroju poetyckiego, symbolizowanego przez, nieobcą twórczości lirycznej autora $^{16}$, metaforę orlich skrzydeł z hiperbolicznym uniżeniem (robak), jak słusznie pisze Marcin Cybulski, tworzy efekt ciekawego kontrastu, którego korzeni ponownie poszukiwać należy w literaturze baroku ${ }^{17}$.

11 Ibidem, s. 406.

12 Zob. S. Nieznanowski, Matka Boska w poezji baroku i czasów saskich, [w:] Matka Boska w poezji polskiej, t. 1, s. 48-49.

13 W. Odymalski, Obleżenie Jasnej Gory Częstochowskiej, [w:] Matka Boska w poezji polskiej, t. 2. Antologia, oprac. M. Jasińska et al., Lublin 1959, s. 50.

14 W. Kochowski, Ofiarowanie poesim polskiej Naświętszej Pannie Maryjej, [w:] Matka Boska w poezji polskiej, t. 2, s. 55.

15 Z.Sz. Feliński, Prośba o natchnienie, s. 406.

${ }^{16}$ Analogiczna metafora występuje w wierszu zatytułowanym Odrętwienie opublikowanym w „Biesiadzie Literackiej” 1902, nr 23, s. 447: „Niech tylko pękną te szatańskie sidła,/ Niech harda wola skruszy się przed Panem,/ A wnet duch orle rozwinie znów skrzydło,/ Znowu uczucie wybuchnie wulkanem!".

17 Zob. M. Cybulski, op. cit., s. 379. 
Zgodnie z zapowiedzią zawartą w Prośbie o natchnienie, tematykę maryjną Zygmunt Szczęsny Feliński konsekwentnie i skrupulatnie podejmuje w kolejnych utworach, pośród których na szczególną uwagę zasługuje Nowy wianuszek majowy z tajemnic życia Maryi na Jej cześć uwity, wydany w 1906 roku, po śmierci arcybiskupa, staraniem Zgromadzenia Rodziny Maryi.

Feliński będący poetą wyłącznie ,na spacerach" ${ }^{18}$, nisko oceniał wartość artystyczną „wierszy majowych”. W liście do Aleksandra Walickiego z 1888 roku Szczęsny pisał o swoich obawach, jakoby owe liryki ponieść miały całkowite fiasko, ,gdyż prócz kilku udatniejszych pieśni, w których przebija promyk natchnienia, inne kute są na zimno jak szkolne ćwiczenia"19. W 1890 roku zesłaniec ponownie powtórzył negatywną opinię o swoich utworach, twierdząc, że myślał o ich opublikowaniu tylko ze względu na pozytywne zdania ,zbyt różowo patrzących przyjaciół". Ostatecznie za życia autora Pamiętników do druku tych wierszy nigdy nie doszło ${ }^{20}$.

Nowy wianuszek majowy to zbiór 34 tekstów stanowiących wierszowaną opowieść o życiu Matki Boskiej oraz Jezusa, uwzględniającą wszystkie najważniejsze etapy ich życia ${ }^{21}$. Feliński, kreśląc żywot Maryi i Jej Syna, sięga przede wszystkim po fakty znane z Ewangelii oraz Dziejów Apostolskich, czyli ksiąg, z których zaczerpnięte cytaty w większości stanowią motta poszczególnych fragmentów. Jednakże utwory zgromadzone w Wianuszku nie są pozbawione elementów o charakterze apokryficznym, do których należą różne nadzwyczajne, niesamowite zjawiska takie, jak towarzyszące przyjściu na świat Maryi (Narodzenie N.M.P.): śpiewy ptaków i owadów, wszelkie „błyski” nad Jej kołyską, unoszące się anielskie chóry, a także pojawiające się znaki na niebie:

Czemu niebo tak jaśnieje

Jakiemś światłem nowem?

Czemu błękit promienieje

Blaskiem purpurowym?

Czy to słońce w północ wschodzi,

Czy zorza się pali? ${ }^{22}$

18 „Zwykle, wychodząc na przechadzkę, brałem do kieszeni małą książeczkę do notatek opatrzoną ołówkiem i obrawszy przedmiot i formę, układałem w pamięci strofy, które wnet przenosiłem na papier, a wróciwszy do domu, przepisywałem i ostatecznie wykończałem". Z.Sz. Feliński, $P a-$ miętniki, oprac. E. Kozłowski, Warszawa 2009, s. 604-605.

19 H.E. Wyczawski, Arcybiskup Zygmunt Szczęsny Feliński 1822-1895, Warszawa 1975, s. 392.

20 Ibidem.

21 Por. F. Ziejka, Błogosławiony Zygmunt Szczęsny Feliński - poeta, [w:] Rodzina Maryi. Dzieło błogosławionego Zygmunta Szczęsnego Felińskiego 1857-2007. Materiały z sympozjum, red. J. Wołczański, Kraków 2009, s. 58-59.

22 Z.Sz. Feliński, Nowy wianuszek majowy z tajemnic życia Maryi przez arcybiskupa Szczęsnego Felińskiego na Jej cześć uwity..., s. 6. 
Autor przywołuje również niepotwierdzone przez Pismo Święte legendy wypełniające dzieje dzieciństwa Jezusa sprawiającego, że: „W skwarnej pustyni źródła tryskają,/ Mają się drzewa,/ Palmy wśród zimy owoc wydają,/ Ziemię deszcz zlewa"23.

W całym zbiorku Szczęsnego nie brakuje „chrześcijańskiej cudowności” opierającej się na ingerencji sił świata nadprzyrodzonego w „realnym planie wydarzeń". Niejednokrotnie w akcji biorą udział aniołowie (Narodzenie N.M.P., Zwiastowanie, Adoracya pastuszków, Wniebowzięcie), Bóg ostrzega przed niebezpieczeństwem (Ucieczka do Egiptu), z nieba dają się słyszeć głosy (Ofiarowanie), Jezus czyni cuda (Wesele w Kanie Galilejskiej) ${ }^{24}$.

Życiu Maryi przed narodzinami Chrystusa Feliński poświęca siedem utworów: Niepokalane poczęcie, Narodzenie N.M.P., Ofiarowanie, Zaślubiny, Zwiastowanie, Nawiedzenie oraz Podróż do Betleem.

Niepokalane poczęcie to wiersz, w którym Feliński, tworząc mroczny, pełen grozy obraz świata opanowanego przez zło i grzech, wyjaśnia, dlaczego potrzebne było zesłanie Jezusa na ziemię ${ }^{25}$ :

Ziemia czartu w moc oddana

Morzem krwi i łez zalana,

Wyczekuje Zbawcy swego

By ją wyrwał z mocy złego ${ }^{26}$.

Arcybiskup w doborze środków obrazowania (krew, łzy), kreacji Boga gniewnego, sprawiedliwego, ale i miłosiernego, ponadto określając człowieka jako byt ,mizerny, niewierny, niewdzięczny, błądzący, grzeszny”, wciąż ewidentnie inspiruje się barokiem ${ }^{27}$.

Z woli Pana matką Chrystusa ma zostać Maryja, która jako jedyna z ludzi narodzi się wolna od grzechu pierworodnego „cudem nad pojęcie/ Nie zna skazy Jej poczęcie"28. Wiersz kończy się, charakterystyczną dla całego cyklu, a występującą często w średniowiecznych pieśniach maryjnych, strofą ,,pochwalno-błagalną” skierowaną do Najświętszej Panny ${ }^{29}$ :

Bądź-że wiecznie uwielbiona

Ty, coś grzechem nieskażona,

Gwiazdo Morza, Niebios Pani!

Serca Tobie niesiem w dani,

Racz je ogrzać i zapalić,

By Cię godnie mogły chwalić ${ }^{30}$.

23 Ibidem, s. 33.

24 Por. T. Michałowska, Średniowiecze, Warszawa 2006, s. 604.

25 Por. M. Cybulski, op. cit., s. 380-381.

26 Z.Sz. Feliński, Nowy wianuszek majowy..., s. 4.

27 Por. M. Cybulski, op. cit., s. 380-381.

28 Z.Sz. Feliński, Nowy wianuszek majowy..., s. 5.

29 M. Cybulski, op. cit., s. 388.

30 Z.Sz. Feliński, Nowy wianuszek majowy..., s. 6. 
Zgodnie z chronologią wydarzeń kolejny tekst dotyczy narodzenia Maryi — „Pani i Królowej stworzenia wszystkiego" ${ }^{1}$. W omawianym utworze przyszła Matka Jezusa zostaje przedstawiona jako „mała dziecina” odpoczywająca w ,ubogiej kolebce”. Jak już wspomniano powyżej, arcybiskup szczególnie podkreśla cudowność zjawisk towarzyszących narodzeniu Maryi. W Ofiarowaniu Feliński, odwołując się do tradycji apokryficznej, przypomina o złożonym przez Matkę Boską ślubie zachowania czystości i o Jej służbie w świątyni. W wierszu zostają także subtelnie zaprezentowane cnoty głównej bohaterki: mądrość, pobożność, pracowitość oraz bardzo ogólne cechy wyglądu zewnętrznego młodej Maryi: „dziewczę małe, płonące cudną krasą”, mające „,liczko jak różyczka”32. Autor w owych lakonicznych określeniach oszczędza czytelnikom bardzo popularnych w średniowiecznych żywotach Matki Boskiej drobiazgowych, a wręcz katalogowych opisów Jej urody, zawartych na przykład w Rozmyślaniu przemyskim czy w apokryficznym dodatku do Kazań o Maryi Pannie czystej Jana z Szamotul (Paterka) ${ }^{33}$.

Zaślubiny to, zgodnie z tytułem, utwór mówiący o małżeństwie Maryi i Józefa, po którym w Wianuszku zostaje zamieszczone Zwiastowanie, jeden z ciekawszych tekstów w całym zbiorze, oparty na wydarzeniach opisanych w Ewangelii wedtug Łukasza i wykazujący spore pokrewieństwo z dawnymi pieśniami zatytułowanymi: O zwiastowaniu Syna Bożego Naświętszej Pannie Maryjej, Matce Bożej oraz Mocne Boskie tajemności.

Feliński, wbrew przekazowi ewangelicznemu, określa nie tylko miejsce Zwiastowania — „komnata”, lecz także porę dnia — „rozświt”, co oznacza, że całe wydarzenie miało miejsce w godzinach porannych. Anioł Gabriel zastaje Maryję przy modlitwie, w której prosi Boga, aby zgodnie z obietnicą — „Wszakeś Panie miłosierny/ Słowu wierny"34, zesłał Zbawiciela:

A czas w Piśmie zakreślony

Już spełniony.

Niechże Zbawca obiecany

Będzie dany.

Niech świat cały cześć ogłasza

Mesyasza $^{35}$.

Analogiczną scenę odnajdujemy we wspomnianej pieśni $O$ zwiastowaniu Syna Bożego..., z tą jednak różnicą, że Zwiastowanie w tym tekście odbywa się o północy ${ }^{36}$. Matka Boska w utworze Felińskiego na widok Anioła „truchleje”,

31 Ibidem, s. 7.

32 Ibidem, s. 9.

33 Zob. S. Sawicki, op. cit., s. 21.

34 Z.Sz. Feliński, Nowy wianuszek majowy..., s. 13-14.

35 Ibidem, s. 13.

36 Ozwiastowaniu Syna Bożego Naświętszej Pannie Maryjej, Matce Bożej, [w:] M. Bobowski, Polskie pieśni katolickie od najdawniejszych czasów do końca XVI wieku, Kraków 1893, s. 302-303. 
a przyniesiona przez niego nowina trwoży Ją, zdumiewa, zawstydza, jak w Mocnych Boskich tajemnościach, gdzie po słowach Gabriela Maryja „staje się czerwona jak róża"37.

Stefan Sawicki uważa, że „,wszystkie te szczegóły przenoszące punkt ciężkości całej sceny na postać Maryi, na przeżycie przez nią chwili Zwiastowania, na to wszystko, co wiąże się, w sposób anegdotyczny ze zwięzłą i rzeczową relacją Łukasza, nadają Bożej Matce i jej reakcjom znamię naturalności i prostoty"38.

Nawiedzenie Elżbiety, podróż do Betlejem to ostatnie chwile z życia Maryi przed narodzeniem Syna w „ubogiej grocie”. W utworze Boże Narodzenie Najświętsza Panna nie tylko z matczyną czułością opiekuje się ukochanym dzieckiem, położonym „,W żłóbku, na sianku”, ale również oddaje mu cześć należną Zbawcy ludzkości, padając przed małym Jezusem na kolana.

Od chwili pojawienia się Chrystusa na świecie losy Maryi nierozerwalnie splatają się z kolejami egzystencji umiłowanego Syna. Adoracya pastuszków, Pokłon Trzech Króli, Rzeź niewiniątek, Ucieczka do Egiptu to utwory, w których Feliński powraca do tematyki maryjnej wyłącznie w końcowych, modlitewnych zwrotach do Matki Boskiej: „Matko, co widzisz żal nasz w tej chwili/ Wstaw się za nami,/ Abyśmy grzechy nasze obmyli/ Pokuty łzami" 39 .

Do wierszy mówiących o zdarzeniach z dzieciństwa Jezusa zaliczają się także: Obrzezanie przybliżające zawarty w tytule specyficzny rytuał kultury judaistycznej oraz Oczyszczenie przybierające z kolei, w początkowych wersach, formę hymnu pochwalnego na cześć Maryi - wzoru godnego naśladowania.

Pozostanie $w$ kościele, Życie ukryte w Nazarecie, Zgon świętego Józefa to teksty poświęcone w Wianuszku życiu Matki Boskiej i Jezusa po powrocie z Egiptu ${ }^{40}$. W tych utworach kreacja Maryi zostaje wzbogacona o bardzo istotny pierwiastek „ludzki”, którego eksponowaniu służy opisywanie rozterek, emocji, uczuć Najświętszej Panny, tak jak ma to miejsce w epizodzie zaginięcia dwunastoletniego Chrystusa:

Gdzież mój Jezus, ma dziecina?

Gdzie pieszczota ma jedyna?

Gdzie ma radość, szczęście, chwała?

Gdzie pociecha moja cała?

Tak Maryja wśród łez jęczy,

Bo ją straszna trwoga dręczy

O Synaczka jedynego,

Gdzieś w podróży zbłąkanego ${ }^{41}$.

37 Mocne Boskie tajemności, [w:] M. Bobowski, Polskie pieśni katolickie..., s. 57.

38 S. Sawicki, op. cit., s. 20.

39 Z.Sz. Feliński, Nowy wianuszek majowy..., s. 34.

40 Por. M. Cybulski, op. cit., s. 383.

41 Z.Sz. Feliński, Nowy wianuszek majowy..., s. 35. 
Łzy Maryi kilkakrotnie pojawiające się w Wianuszku (Zgon św. Józefa, Obrzezanie, Osamotnienie Maryi, Spotkanie na Kalwaryi) są wyrazem bólu i naturalnym dla każdego człowieka sposobem ujawniania zmartwień i trosk ${ }^{42}$.

Śmierć Józefa rozpoczyna w życiu Matki Boskiej trudny etap rozstań z najbliższymi. Wkrótce opuszcza Ją również dorosły Jezus rozpoczynający swą działalność. Osamotnienie Maryi to wiersz, w którym Feliński ponownie powraca do ludzkiego aspektu osobowości Bożej Rodzicielki — zwyczajnej matki tęskniącej za dzieckiem, oczekującej o nim wieści.

Hieronim Wyczawski uważa, że na dość melancholijną nutę utworu wywarła wpływ osobista sytuacja autora, który przebywał i tworzył na zesłaniu ${ }^{43}$. W słowach: ,Więc, o Pani! przez łzy ciche/ Lane w samotności,/ Przyjm te nasze pieśni liche/ Jako hołd miłości" 44 , wspomniany badacz i potwierdzający jego spostrzeżenia Marcin Cybulski dopatrują się elementów biograficznych ${ }^{45}$.

Wesele w Kanie Galilejskiej, w przeciwieństwie do Osamotnienia Maryi, jest tekstem pełnym pogodnej, wesołej, biesiadnej atmosfery, z postacią szczęśliwej Matki Boskiej widzącej, jak za sprawą Jezusa, ku uciesze weselników, woda przemienia się w wino.

Ostatnia wieczerza, Spotkanie na Kalwaryi, Maryja pod krzyżem, Siedm stów na krzyżu to narracyjne opowieści o ostatnim etapie ziemskiego życia Chrystusa, zakończonego śmiercią na krzyżu, zmartwychwstaniem i wniebowstąpieniem. Dramatyzm naturalistycznych scen męki Jezusa (,zsiniałe oblicze”, „rany”, ,sińce”, „rozkrwawiające się rany”, „zbolałe ciało”, „wpijająca się w skronie korona cierniowa”, ,ściekająca krew”, „lejący się pot zmieszany z krwią”), charakterystycznych dla staropolskich pasji ${ }^{46}$, pogłębia uczestnictwo w nich zrozpaczonej, strapionej, współcierpiącej Maryi („,Póki Syn cierpi — cierpi z Nim społem;/ Gdy żyć przestaje - wspólnie z Nim kona"47), której na widok umęczonego, zhańbionego dziecka ,serce z boleści się kraje" ${ }^{48}$. Niezwykle emocjonalnym fragmentem w Wianuszku jest opis spotkania dźwigającego krzyż Jezusa z Matką, gdy „Padłszy nawzajem sobie w ramiona/ W niemej boleści łzy swe mieszają"49.

Kolejne utwory: Złożenie do grobu, Opieczętowanie grobu, Zmartwychwstanie, Pobyt na ziemi po zmartwychwstaniu, Wniebowstapienie, Zestanie Ducha świętego, powracające do formy wierszowanej, jak wskazują same tytuły, odno-

42 Zob. S. Nieznanowski, Matka Boska w poezji baroku i czasów saskich, s. 54.

43 H.E. Wyczawski, op. cit., s. 392.

44 Z.Sz. Feliński, Nowy wianuszek majowy..., s. 46.

45 Zob. M. Cybulski, op. cit., s. 384.

46 Zob. T. Michałowska, op. cit., s. 611-612.

47 Z.Sz. Feliński, Nowy wianuszek majowy..., s. 57.

48 Ibidem, s. 58.

49 Ibidem, s. 56. 
szą się do Jezusa. Maryja pojawia się w tych tekstach wyłącznie epizodycznie. Oto na przykład wsparta na ramieniu Jana udaje się złożyć ciało Syna do grobu czy też spotyka zmartwychwstałego Jezusa w swojej komnacie:

Choć z ksiąg żadna nie stwierdziła,

W jakim czasie zaszło to,

Iż Maryja dostąpiła

Szczęścia oglądania Go;

Wiemy, że gdy w swej komorze,

Jak podania twierdzi głos,

Wylewała łzy w pokorze,

Pierwszą spotkał Ją ten $\operatorname{los}^{50}$.

Do właściwej dla Wianuszka tematyki maryjnej Feliński powraca w nostalgicznym wierszu zatytułowanym Tęsknota Maryi, który tematycznie łączy się z omówionym w niniejszych rozważaniach Osamotnieniem Maryi. Matka Boska, z woli autora, ponownie zostaje przedstawiona w bardzo ludzkim aspekcie jako tęskniąca za dawnym, szczęśliwym życiem z rodziną w Nazarecie, samotna (,W koło Ją pustka otacza głucha" ${ }^{51}$ ) kobieta, coraz częściej myśląca o śmierci jako jedynej możliwości ponownego połączenia się z Synem (,,To też Maryja tęskni za zgonem,/ Co Ją połączy z Synem na nowo"52).

Opracowany przez arcybiskupa poetycki życiorys Maryi kończy wiersz Wniebowzięcie, odwołujący się do jednego z najstarszych elementów mariologii katolickiej, jakim jest przekonanie, że po śmierci Matka Boska została wraz z ciatem i duszą wzięta do nieba ${ }^{53}$.

Plan wydarzeń w utworze Felińskiego przedstawia się następująco: do Maryi przybywa anioł, który informuje Ją, iż za chwilę „wyjdzie z ciała”, po czym „Jej powieki/ Śmiertelny sen zwarł na wieki/ A wolny duch z łez krainy,/ Uleciał wnet w te wyżyny,/ Kędy się łza już nie leje,/ I kędy czas nie istnieje"54. Następnie wśród anielskich śpiewów i cudownych blasków „wnet Dziewica/ Powstaje z mar" ${ }^{\circ 5}$ i zasiadając na jasnych skrzydłach Archanioła, zostaje uniesiona do nieba.

Feliński, arcybiskup warszawski wytrwale dążący do upowszechnienia w Archidiecezji nabożeństwa majowego ${ }^{56}$, w swojej twórczości literackiej głosi wielką pochwałę miesiąca maja jako tego szczególnie poświęconego kultowi Matki Bo-

50 Ibidem, s. 78.

51 Ibidem, s. 87.

52 Ibidem, s. 88.

53 Zob. S. Napiórkowski, Maryja w teologii, [w:] Encyklopedia katolicka, t. 12, s. 20.

54 Z.Sz. Feliński, Nowy wianuszek majowy..., s. 89.

55 Ibidem, s. 91.

56 „Co do czci N.P. Marii, chodzi mi głównie o nabożeństwo majowe. Jest ono powszechne w całym świecie katolickim. Chciałbym, by odtąd nabożeństwo to stało się obowiązującym dla wszystkich kościołów. Najpożądańsze byłyby przy tym codzienne nauki, żywy głos kapłana. Gdzie zaś ku temu nie ma możności, tam przynajmniej czytaniem, śpiewaniem, przystrojeniem ołtarza pobożność ludu podniecać trzeba". Z.Sz. Feliński, Pamiętniki, s. 549. 
skiej. Warto w tym miejscu wspomnieć, że wiersze z Nowego wianuszka majowego, w wydaniu przygotowywanym przez Szczęsnego, umieszczone były w książeczce o znamiennym tytule: Nabożeństwo majowe z pieśni i rozmyślań ułożone, które zawierało również odpowiednie refleksje na każdy dzień maja. Niestety wydawcy dotychczas współpracujący z autorem (Miłkowski, Walicki) nie podjęli się publikacji tego dziełka, w wyniku czego dopiero w 1909 roku trafiło ono do rąk czytelników ${ }^{57}$.

Urokom maja, ze szczególnym podkreśleniem jego religijnego wymiaru, Feliński poświęcił dwa liryki: Miesiąc maj oraz Rozmowę Zosi z Matką. Obydwa utwory mają wyraźnie sielankowy charakter. Miesiąc maj składający się z pięciu strof, z których każda liczy po cztery wersy, pisany regularnym ośmiozgłoskowcem, przypominający trochę prostą „rymowankę” dobitnie obrazuje piękno maja - kwitnące kwiaty (bławatki), krzewy (polne głogi), zieleniejące się liście w gajach. Budząca się na wiosnę przyroda oddaje hołd Maryi, do czego podmiot liryczny zachęca również ludzi słowami:

Spieszmy także lube dziatki,

Złożyć hołdy Niebios Pani:

Wdzięczne pienia, świeże kwiatki

Dla Maryi nieśmy w dani ${ }^{58}$.

W Rozmowie Zosi z Matka ${ }^{59}$ Feliński ponownie pisze o majowych, kwitnących łąkach, śpiewającym skowroneczku, zieleniejących się gajach wspólnie wielbiących Maryję, a także o przystrojonym kwiatami obrazie Przenajświętszej Panny, odzwierciedlającym ludowy charakter kultu maryjnego. Dodatkowo obydwa utwory rozpoczynają się niemal identycznie: „Znowu wiosna, maj powrócil” (Rozmowa ..., s. 2), „Znów nam wrócił miesiąc drogi” (Miesiąc maj, s. 641). Nietrudno też nie zauważyć, że trzy pierwsze strofy Miesiąca maja tematycznie odpowiadają monologowi Zosi z Rozmowy (opisy natury), przy czym dwie ostatnie zwrotki podobnie jak wypowiedź Matki mają charakter pouczający, sprowadzający się do tezy, że Maryi największą radość sprawiają przede wszystkim: głęboka wiara, wewnętrzna przemiana człowieka (,Że najmilsze z wszystkich dary/ Matce Boskiej ten poświęci/ Kto poprawi swe przywary”"60) oraz cnoty: „wstydliwość”, „niewinność”, „skromność”.

Zygmunt Szczęsny Feliński w Rozmowie Zosi z Matka, bez wątpienia adresowanej do młodego odbiorcy ${ }^{61}$, wprowadza czytelnika w świat symboliki kwiatów poświęconych Maryi, pośród których prym wiodą: lilia — symbol czystości,

57 Zob. H.E. Wyczawski, op. cit., s. 404.

58 Z.Sz. Feliński, Miesiąc maj, „Echo Trzeciego Zakonu św. O. Franciszka” 4, 1887, nr 11, s. 641 .

59 Z.Sz. Feliński, Rozmowa Zosi z Matka, [w:] Nowy wianuszek majowy..., s. 2-3.

60 Z.Sz. Feliński, Miesiąc maj, s. 641.

61 Z.Sz. Feliński dedykuje swoje utwory ludziom młodym. Dla dziewcząt szukających drogi życiowej arcybiskup przeznaczył Konferencje o powołaniu. Ku ,,pokazaniu młodzieży niejednej użytecznej prawdy i podniesienia nieco zbyt poziomego polotu uczuć" stworzył Praksedę oraz 
wybrania, niewinności ${ }^{62}$, róża podkreślająca królewską godność Matki Boskiej, w kolorze czerwonym również Jej miłość, cierpienie oraz fiołek - barwą przypominający niebo, przez co oznacza uduchowienie, kontemplację, pokorę cechujące Bogarodzicę ${ }^{63}$.

Wśród dotychczas omówionych pomysłów arcybiskupa w zakresie występujących w jego utworach motywów maryjnych próba opisania trudów, z jakimi boryka się malarz tworzący obraz Madonny, swoje źródło ma w twórczości polskich romantyków ${ }^{64}$. Stella Fornarina. Ustęp z życia Rafaela Władysława Syrokomli, Teofila Lenartowicza Album włoskie (postaci Rafaela i Fra Beato Angelico), wiersz Franciszka Żyglińskiego Do malarza pracujacego nad obrazem Najśw. Panny (w listopadzie 1847 roku), jak stwierdza Andrzej Paluchowski, są dziełami „ukazującymi różne aspekty kornej czci i zachwytu artystów dla Matki Bożej”65. W przeciwieństwie jednak do Lenartowicza i Syrokomli Feliński nie czyni bohaterem pierwszej „odsłony” dramatu Oskar $i$ Wanda żadnego z ,wielkich malarzy”. W utworze arcybiskupa to Tekla (postać fikcyjna) — przyszła zakonnica, wpatrzona w marmurową rzeźbę Maryi „odbijającą tylko spokój i czystą piękność Anielskiej Królowej" ${ }^{\prime 26}$ — maluje Jej obraz, który pragnie podarować swojemu bratu Oskarowi. Artystycznym zamiarem dziewczyny jest stworzenie wizerunku Matki Boskiej, który wyrażałby: „To miłosierdzie Jej niewyczerpane,/ Co nas ota-

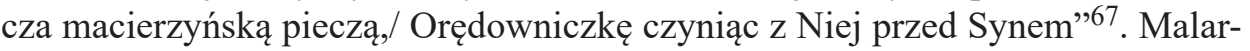
kę szczególnie interesuje wyraz twarzy Maryi stojącej pod krzyżem. Tekla uważa bowiem, że to wówczas na szczycie Golgoty z oblicza Najświętszej Panny, obok bólu i cierpienia, najpełniej promieniowała miłość do ludzi i Syna:

W takim spojeniu, jak tęczowe barwy,
Co w jasny promień słońca się zlewają.
Radość, że okup ludzi dokonany, [...]
I to za sprawą najmilszego Syna,
Pewno jaśniała na twarzy Maryi
Obok boleści, że Syn w mękach kona ${ }^{68}$.

Oskara i Wandę. Z dedykacją dla siostrzenic i bratanic powstała Paulina córka Ewy Felińskiej. Uznając natomiast za swoją powinność „opowiedzieć młodszemu pokoleniu to, na co patrzałem, a co z dniem każdym coraz więcej zaciera się w pamięci narodu, coraz to cięższym nękanego utrapieniem”, Feliński napisał Pamiętniki.

62 Lilia, [w:] M. Lurker, Stownik obrazów i symboli biblijnych, przeł. K. Romaniuk, Poznań 1989, s. 116.

63 T. Basiura, Kwiaty Maryi, www.katolik.pl/kwiaty-maryi,2499,414,cz.html [dostęp: 22.08.2015].

64 A. Paluchowski, Matka Boska w poezji czasów stanisławowskich i okresu romantyzmu, [w:] Matka Boska w poezji polskiej, t. 1, s. 97.

65 Ibidem.

66 Z.Sz. Feliński, Oskar i Wanda. Obraz dramatyczny z teki Anhellego, oprac. T.A. Frącek RM, Szczecinek 2010, s. 102.

67 Ibidem.

68 Ibidem. 
Zadając pytanie: ,Jak oddać pędzlem, co rozum zdumiewa?...”69, bohaterka zastanawia się, w jakim stopniu człowiek jest w stanie zrozumieć i wyrazić na płótnie niepojęte, boskie tajemnice. Wzorem Fra Giovanniego ${ }^{70}$, który wedle legendy tworzył swe obrazy klęcząc, Tekla pada na kolana i nie przestając malować, gorąco modli się do Maryi o dar poznania i trafne ujęcie artystycznej wizji:

Matko miłości i litości wzorze,

Spuść promień światła z tronu Twojej chwały,

Rozpędź ciemności wzroku cielesnego

I daj mi ujrzeć czystym okiem ducha

Twoje najświętsze oblicze, o Pani ${ }^{71}$.

Analogicznym motywem modlitwy posługuje się również poeta-malarz Franciszek Żygliński w wierszu Do malarza ... — ,Jak w duszy mojej słonecznie mi świecisz/ Tak spraw, bym odblask Twój w płótno w obraził./ Kiedyż, o kiedyż, barwą mi rozświecisz/ Pierwowzór, który Bóg w mą duszę wraził?"72.

Chwila tworzenia przez Teklę jej dzieła, pełna skupienia, pokory, kontemplacji, z woli Felińskiego zostaje zupełnie pozbawiona wybuchu twórczego uniesienia/szału, jakim cechuje się na przykład scena przypływu natchnienia Rafaela ze Stelli Fornariny:

I ujął pędzle, i w szybkim zachwycie

Począł malować oblicze Madonny:

Za każdym rysem wstępowało życie

W utwór mistrzowski z pod ręki natchnionej;

$\mathrm{Z}$ oczu blask bije, rumieńce goreją,

Zda się oddycha dziewa jasnowłosa ${ }^{73}$.

Nie bez znaczenia jest przywołanie przez Szczęsnego postaci Fra Giovanniego jako opiekuna artystycznej działalności bohaterki. Decyzji Felińskiego zapewne przyświecała nade wszystko myśl wyboru malarza sięgającego po tematykę sakralną, będącego jednocześnie osobą duchowną, którą pragnęła zostać także Tekla. Być może do głosu doszedł tu wyraz prywatnej sympatii autora dla tegoż twórcy, co z kolei trudno jednoznacznie potwierdzić. O ile bowiem z Pamiętników, listów dowiadujemy się o gustach czytelniczych arcybiskupa, o tyle o jego

69 Ibidem.

70 Guido di Pietro, imię zakonne Fra Giovanni da Fiesole (dominikanin), nazywany również Fra Angelico - to włoski malarz okresu wczesnego renesansu, twórca malowideł ściennych w klasztorze św. Marka we Florencji, fresk w katedrze w Orvieto, dekoracji w prywatnych apartamentach papieskich i zdobień w kaplicy Pałacu Watykańskiego. Beatyfikowany przez Jana Pawła II w 1982 r., obecnie jest patronem artystów oraz historyków sztuki.

71 Z.Sz. Feliński, Oskar i Wanda, s. 103.

72 F. Żygliński, Do malarza pracującego nad obrazem Najśw. Panny (w listopadzie 1847 roku), [w:] idem, Zbiór poezyi śp. Franciszka Żyglińskiego, Kraków 1852, s. 62.

73 W. Syrokomla, Stella Fornarina. Ustęp z życia Rafaela, Mińsk 1859, s. 71. 
upodobaniach w zakresie innych sztuk niestety nie za wiele. Zdaje się, że w tym przypadku słuszną tezą byłaby i ta mówiąca o wielkim, jakże istotnym wpływie kultury, literatury romantycznej, na twórczość pisarza.

Warto również odnotować, że w Oskarze $i$ Wandzie Feliński wprowadził jeszcze jeden niezwykle interesujący motyw maryjny, jakim jest podziwianie dzieła stworzonego ku czci Matki Boskiej. Tekla spoglądając na umieszczony w swojej pracowni, nieokreślony szczegółowiej, posąg Madonny, z zachwytem mówi: „Widać, że dłuto rzeźbiarza artysty/ Było natchnione szczytną myślą z Nieba/ W chwili, gdy tworzył tę Madonnę cudną" "74.

Zgodnie z rozważaniami Andrzeja Paluchowskiego korzeni tej idei ponownie należy poszukiwać w twórczości romantyków, podobnie jak występującego w Praksedzie motywu niewidomego lirnika głoszącego chwałę Przenajświętszej Panny Poczajowskiej ${ }^{75}$.

W utworach Zygmunta Szczęsnego Felińskiego obraz z wizerunkiem Matki Boskiej pojawia się przy okazji kreacji bohatera-malarza jako przedmiot jego pracy, a także stanowi bardzo ważny składnik wnętrz domów. Znajduje się on bowiem zarówno w „,biednej chatce” Zosi (Rozmowa Zosi z Matka), jak i w szlacheckim ,starym zamku” Wojewody — dzielnego obrońcy ojczyzny (Prakseda).

W Praksedzie jednak arcybiskup nie ogranicza się wyłącznie do zasygnalizowania istnienia w ,świecie przedstawionym” utworu - oświetlonego lampą obrazu „Przeczystej Dziewicy,/ Co jak jutrzenka w klejnotach jaśnieje”,76, lecz w baśniowy sposób opisuje również miejsce, w którym się znajduje:

W narożnej wieży, od strony ogrodu,

Leży podłużna, sklepiona komnata,

Słońce w jej wnętrze zagląda od wschodu,

A ściany kryje turecka makata.

Na oknach krzewy mają się kwiatami:

Te jak śnieg białe, w tych barwy się mienią,

A wśród nich klatki ludne ptaszętami,

Co śpiew swój wdzięczny z wonią kwiatów żenią ${ }^{77}$.

Promienie słońca, śpiew ptaków, kwiaty, wszechobecne piękno i jasność w połączeniu ze lśniącym obrazem wspólnie tworzą aurę niesamowitości, cudowności. Ta niezamieszkana przez bohaterów komnata, do której udają się wyłącznie na modlitwę, nabiera szczególnego, religijnego wymiaru, stając się „,domową świątynią" rodziny Praksedy. Feliński, kontrastując to miejsce z ponurą, ciemną izbą Wojewody przypominającą więzienie (grube ściany, wąskie okna z kratami), wypełnioną wszelkiego rodzaju bronią (,buzdygany, berdysze, tarcze, kopie,

74 Z.Sz. Feliński, Oskar i Wanda, s. 102.

75 A. Paluchowski, op. cit., s. 97.

76 Z.Sz. Feliński, Prakseda. Legenda z teki Anhellego, oprac. T.A. Frącek RM, Szczecinek 2010, s. 42.

77 Ibidem, s. 41. 
wschodnie jatagany, dziryty, szable, koncerze"78) oraz elementami zbroi (,,hełmy, hartowne pancerze, włoskie misiurki"79), tworzy znaną opozycję, skupioną wokół dwóch pojęć: sacrum-profanum.

Występujące w utworach Felińskiego motywy ,ikonografii maryjnej”"80 wstępnie można podzielić na dwie grupy. Pierwszą reprezentują wizerunki Matki Boskiej, które nie są centralnymi przedmiotami opowieści i pełnią funkcję polegającą na określaniu duchowego dziedzictwa bohaterów (przykład powyższy). Do drugiej grupy należą natomiast cudowne obrazy otoczone wielkim kultem, będące przedmiotem opowieści przekazywanych z pokolenia na pokolenie, wokół których osnuta jest fabuła danego dzieła.

W dorobku Szczęsnego utworem sławiącym poczajowskie sanktuarium ze znajdującym się w nim wizerunkiem Maryi oraz przypominającym historię cudownej obrony tegoż miejsca jest Prakseda. Akcja poematu arcybiskupa rozgrywa się na Wołyniu w drugiej połowie XVII wieku. W leżącym nad brzegami Ikwy zamku Sokolnik mieszka, przygotowujący się do obrony kraju przed nadciągającymi Tatarami, Wojewoda z żoną i córką. Dla bezpieczeństwa bohater odwozi rodzinę do klasztoru w Poczajowie. Po drodze napada na nich oddział wroga. Okazuje się, że dowódcą szczęśliwie pokonanej ,,przebranej bandy” jest pałający zemstą książę Roger, odrzucony przez Praksedę. Mężczyzna udaje się następnie do obozu Tatarów, by przekonać Hassana do wspólnej wyprawy na Poczajów. W czasie narady zostają zaatakowani przez drużynę Wojewody, który ponosi śmierć z ręki Rogera. Tatarzy wdzierają się do klasztoru, a strzała wystrzelona przez księcia w modlący się thum wiernych rani śmiertelnie Praksedę. Wówczas to bijąca z obrazu Matki Boskiej cudowna jasność skłania przerażonych najeźdźców do ucieczki. Książę Roger w dniu pogrzebu ukochanej publicznie przyznaje się do popełnionych zbrodni oraz podejmuje decyzję o pozostaniu w klasztorze. Kolejne dni upływają mu wyłącznie na modlitwie i pełnieniu dobrych uczynków (uczy dzieci ,zasad wiary”, opiekuje się chorymi, niesie pomoc wszystkim potrzebującym). Umiera przy złożonej w podziemiach trumnie Praksedy.

Przedstawiona, w wielkim uproszczeniu, fabuła utworu pełna romantycznych wątków ${ }^{81}$, jak stwierdza Franciszek Ziejka, zawiera „,prawdę starej legendy, jaka zrodziła się w Poczajowie już w II połowie XVII wieku i która żyła bujnym

\footnotetext{
78 Ibidem.

79 Ibidem.

${ }^{80}$ Terminem tym posługuje się również: A. Paluchowski, op. cit., s. 91.
}

81 Zob. M. Cybulski, Romantyczne dziedzictwo Zygmunta Szczęsnego Felińskiego, „Wiek XIX. Rocznik Towarzystwa Literackiego im. Adama Mickiewicza" 5 (47), 2012, s. 225-238. Do motywów romantycznych występujących w Praksedzie, o których autor nie wspomina, należą także: orientalizm (opis tatarskiego obozu, słownictwo), frenezja (sceny walk), „ludowość” (obyczaje pogrzebowe), postać lirnika, blizna/krwawiąca rana, ruiny, tematyka szlachecka (krytyczna ocena „panów braci”). 
życiem także w wieku XIX" ${ }^{82}$. Badacz uważa, że pisarz przywołuje w Praksedzie wydarzenia z 1675 roku, gdy klasztor został napadnięty przez wojska tureckie, tatarskie i ocalony za sprawą ingerencji Matki Boskiej, która wraz z aniołami uzbrojonymi w miecze objawiła się nad cerkwią, otaczając ją swoim płaszczem, w wyniku czego wystrzeliwane strzały tylko się od niego odbijały, raniąc przy tym wystraszonego wroga. Dodatkowo, wedle przekazu, pojmano wówczas wielu jeńców, spośród których część przyjęła później chrześcijaństwo ${ }^{83}$. Feliński musiał znać tę opowieść, a rozpoczynający Pieśn IV opis góry z klasztorem może sugerować, że Szczęsny kiedyś odwiedził to święte miejsce ${ }^{84}$ :

Na płaskim szczycie granitowej skały,
Otoczon wieńcem dębów i kasztanów,
Widnieje z dala kościół okazały,
A przy nim klasztor Ojców Bazylianów.
Na całej Rusi kościół ten jest czczony,
Jako największa świętość narodowa,
Bo w nim cudowny obraz umieszczony,
Co jest odwieczną chlubą Poczajowa ${ }^{85}$.

Trudno nie zgodzić się z Ziejką, że arcybiskup perfekcyjnie wykorzystał wszystkie główne elementy wspomnianej legendy ${ }^{86}$. Feliński tworzy najpierw obraz ojczyzny nękanej przez wroga i pisze o thumach ludzi szukających schronienia w świątyni („Nie będąc w stanie w domu się obronić/ Od grożącego Pohańców napadu,/ Radzi są w murach warownych się schronić,/ Gdzie więcej ludzi, oręża i ładu"87). Wiadomość o klęsce Wojewody wywołuje powszechną panikę: „Dzielniejsi pragną krwawego spotkania,/ Słabszym, mniej śmiałym, rozum walki wzbrania:/ Ucieczkę raczej doradza im trwoga" 88 . Jeden z bazylianów zachęca wówczas wiernych do wspólnych modlitw o ratunek. Tatarzy, przybywszy pod klasztor, który „Choć silnym murem otoczony,/ Oporu wszakże stawiać nie próbuje,/ Z Nieba albowiem czekając obrony" ${ }^{\text {"9 }}$, szybko dostają się do środka. Gdy za przykładem Rogera napastnicy zaczynają strzelać z łuków w rozmodlony, zapłakany tłum, w jego obronie staje Maryja:

Wtem... Cudzie cudów!... Blask ćmi od ołtarza

Rośnie... Napełnia światłem kościół cały...

Obraz cudowny mieni się...Bóg stwarza

Niebiosa żywe w aureoli chwały!...

Blask kształt przybiera... Znika wizerunek,

82 F. Ziejka, Błogosławiony Zygmunt Szczęsny Feliński - poeta, s. 49.

83 Ibidem, s. 50-51.

84 Por. T.A. Frącek RM, Wprowadzenie, [w:] Z. Sz. Feliński, Prakseda, Oskar i Wanda. Dwa poematy z teki Anhellego, Szczecinek 2010, s. 17-18.

85 Z.Sz. Feliński, Prakseda, s. 76.

86 F. Ziejka, Błogosławiony Zygmunt Szczęsny Feliński - poeta, s. 51-52.

87 Z.Sz. Feliński, Prakseda, s. 77.

88 Ibidem, s. 79.

89 Ibidem, s. 85. 
Na jego miejsce widzenie się jawi.

To Przenajświętsza Pani na ratunek

Z Nieba przybywa — i swój lud wybawi!... ${ }^{90}$

Matka Boska Poczajowska „przecudna wieczną młodością”, spoglądając na wiernych „błogosławiącym spojrzeniem”, osłania ich następnie „lazurowym płaszczem", chroniąc od ran, śmierci identycznie, jak w dawnym podaniu. Podobnie i książę Roger nawraca się oraz pełni służbę w klasztorze wzorem najeźdźców z 1675 roku $^{91}$.

Feliński kończy historię cudownej obrony Poczajowa twierdzeniem, że Maryja, znikając, zostawiła ślad swojej stopy na kamieniu, z którego ,żywa trysnęła krynica,/ Co późnym wiekom świadczy o zdarzeniu"92. Zdaje się jednak, że arcybiskup tymi słowami przywołał jeszcze inną legendę, odnoszącą się do wydarzeń znacznie wcześniejszych. Otóż, jak podaje Urszula Anna Pawluczuk, po 1240 roku na Górze Poczajowskiej w ognistym słupie objawiła się Maryja, która obroniła górę i mnichów przed najazdem tatarskim. To właśnie wówczas Bogarodzica zostawiła na skale ślad swojej prawej stopy, słynący z uzdrawiających mocy. Wkrótce po tym cudownym zdarzeniu mnisi wybudowali niedużą cerkiew pod wezwaniem Zaśnięcia NMP. Owa skała przez czterysta lat pozostawała pod gołym niebem i dopiero, gdy w 1649 roku Teodor i Ewa Domaszewscy ufundowali cerkiew, ,stopa” wraz ze źródłem znalazła się w środku świątyni, z prawej strony ikonostasu ${ }^{93}$.

Oparta na legendzie fabuła Praksedy jest bez wątpienia kolejną romantyczną inspiracją w twórczości Szczęsnego. Autor, sławiąc Poczajów, znacząco wpisuje się również w poczet twórców przywołujących w swoich utworach określone wizerunki Matki Boskiej (Tadeusz Łada-Zabłocki Przed obrazem Najśw. Panny Ostrobramskiej, Władysław Syrokomla Hymn do Najświętszej Panny w Ostrej Bramie $^{94}$, Teofil Lenartowicz Najświętsza Maria Panna Studzienniecka, Wincenty Pol Do Najświętszej Panny Marii Częstochowskiej).

Zdaniem Franciszka Ziejki Prakseda sięga jednak do tradycji znacznie starszej niż romantyzm i zalicza się do kręgu opowieści mówiących o „,cudownej obronie świątyni” (obrona świątyni w Delfach w 480 r. p.n.e. przed grabiącym ziemie greckie cesarzem perskim Kserksesem ${ }^{95}$, obrona Konstantynopola przed wojskami Askolda w 626 roku, obrona Salonik w VII wieku, obrona Jasnej Góry w 1655 roku $)^{96}$.

90 Ibidem, s. 86.

91 F. Ziejka, Błogostawiony Zygmunt Szczęsny Feliński - poeta, s. 52.

92 Z.Sz. Feliński, Prakseda, s. 87.

93 U.A. Pawluczuk, Lawra Poczajowska. Pod opieka Matki Bożej i św. Hioba, Białystok 2013, s. 13-14.

94 Zob. T. Krahel, Poezja ostrobramska, Białystok 1996.

95 Zob. F. Ziejka, Cudowna obrona świątyni-miasta, [w:] idem, Miasto poetów. Studia i szkice, Kraków 2005, s. 206.

96 F. Ziejka, Błogosławiony Zygmunt Szczęsny Feliński - poeta, s. 52. 
Motywy maryjne występujące w utworach Felińskiego nie ograniczają się wyłącznie do omówionych tu kwestii. Ilekroć bowiem arcybiskup opisuje sytuację kraju w obliczu fikcyjnego zagrożenia (Prakseda) bądź kreśli rzeczywiste położenie państwa pod zaborami, zawsze dołącza utrzymany w tonacji błagalnej zwrot do Maryi jako Królowej Polski o pomoc.

W Praksedzie tytułowa bohaterka, myśląc o zbliżających się wojskach wroga, modli się do Bogarodzicy w następujący sposób:

Pomnij, żeś Matka nasza i królowa...

Czyż nas Bisurman w niewolę zaprzeda?

Czyż pod miecz pójdzie chrześcijańska głowa?

Patrz! Kmieć ubogi tuła się jak zwierzę,

Niewiasty, dzieci umierają z głodu,

Pohaniec świętej śmie urągać wierze,

I lży świątynie wiernego narodu.

Wstawże się, Matko, do Synaczka swego ${ }^{97}$.

Maryja w świadomości/wyobrażeniach Praksedy jest pośredniczką wypraszającą u Jezusa pokój, pomyślność, szczęście dla swoich poddanych. Również w liryku Tęcza pełnym dramatycznych obrazów egzystencji Polaków ,jęczących w jarzmie trzech morderców” — „spustoszone świątynie, obalone krzyże, rozproszone klasztory, wspaniałe gmachy w gruzy obrócone, zakaz mówienia w języku ojczystym, praca na rzecz zaborcy" 98 — pojawia się apostrofa skierowana do Matki Boskiej — Królowej, w której cały naród pokłada „,ufność”. Motyw ten, częściowo przewijający się w patriotycznej poezji konfederacji barskiej, odnajdujemy także w kończącym Wianuszek wierszu Pożegnanie:

\footnotetext{
I ziemię naszą, którejś Królową,

Srodze też trapi zbawienia wróg,

Tak, że jej dzieci niemal połowa

Już na zaguby wkroczyła próg.

Ujmij się przeto za nas, o Pani!

Usłysz stroskanych dzieci Twych płacz,

Nim serce ludu odstępstwo zrani

Skuteczną pomoc zjednać nam racz ${ }^{99}$.
}

W dobie niewoli narodowej kult Matki Boskiej podkreślający Jej królewską godność miał szczególnie znaczenie. Wzmagał on bowiem przekonanie wśród ludzi, iż cały naród polski znajduje się pod bezpośrednią opieką Bogarodzicy ${ }^{100}$. Feliński w kazaniu wygłoszonym 4 maja 1890 roku w katedrze lwowskiej, odwołując się do ślubów złożonych przez Jana Kazimierza w 1656 roku, uznawanych za formę elekcji Maryi ${ }^{101}$, objaśniał:

97 Z.Sz. Feliński, Prakseda, s. 42.

98 Z.Sz. Feliński, Tęcza, „Tęcza” 1929, z. 18 (w czasopiśmie brak numeracji stron).

99 Z.Sz. Feliński, Nowy wianuszek majowy..., s. 98.

100 Zob. J. Tazbir, Kultura szlachecka w Polsce. Rozkwit - upadek — relikty, Warszawa 1978, s. 111

101 Ibidem, s. 110. 
Wręczenie to berła polskiego Bożej Rodzicielce oznacza nadto, iż wszystkie prawa rządzące podległym Jej krajem winny być tak zgodne z duchem Ewangelii, iżby je Matka Jezusowa za swoje przyznać mogła, obyczaje zaś ludu tak skromne i uczciwe, by patrząc na nie Przeczysta Panienka, rumienić się za swych poddanych nie potrzebowała ${ }^{102}$.

Szczęsny przekonywał, że w obliczu utraty niepodległości, na nic nie przydadzą się same skargi kierowane do Matki Boskiej, jeżeli naród nie spojrzy na własne dzieje, nie dostrzeże wad, które upadek spowodowały i nie odrodzi się na nowo pod względem religijnym oraz moralnym.

Do istotnych motywów maryjnych pojawiających się w utworach Felińskiego należą modlitwy skierowane do Maryi. W związku z tym, że w niniejszym artykule ów temat pojawiał się przy okazji opracowywania innych zagadnień, ograniczmy się w tym miejscu wyłącznie do sformułowania ogólnego wniosku.

Modlitewne zwroty do Matki Boskiej mają różny charakter. Obok artystycznych próśb o natchnienie, błagań o dobro ojczyzny — wynikających z pobudek patriotycznych - spotykamy w dziełach Szczęsnego także piękne w swej prostocie, wierszowane modlitwy o pocieszenie, wsparcie, wstawiennictwo u Syna, wyjednywanie łask, dodawanie sił i otuchy w trudnych życiowych sytuacjach.

Osobista pobożność maryjna Felińskiego, głęboko tkwiąca w polskiej tradycji religijnej, znacząco wpłynęła na jego twórczość literacką. Wychowany w domu pełnym patriotycznej i chrześcijańskiej atmosfery opartej na: miłości Boga, ludzi, prawie Bożym, Ewangelii, szacunku, zaufaniu, codziennej wspólnej modlitwie, znacznie dłuższej, gorętszej w trudnych chwilach dla rodziny (choroba Pauliny, zesłanie Ewy, śmierć ojca), Szczęsny głęboko czcił Matkę Boską. Jako trzynastoletni chłopiec złożył przed obrazem Zwiastowania NMP w kościele w Klewaniu ślub czystości. Jego święcenia kapłańskie odbyły się w dniu święta maryjnego 8 września 1855 roku. Przed przyjazdem do Warszawy, gdzie miał pełnić funkcję arcybiskupa, Szczęsny wstąpił do Częstochowy, by oddać się w opiekę Jasnogórskiej Pani.

Feliński jako pisarz, wytrwale wierząc w moc oddziaływania tekstów na intelektualny, religijny rozwój czytelników, przypisując literaturze bardzo doniosłe funkcje o charakterze społeczno-patriotycznym, jak widzimy, z wielkim upodobaniem sięgał po motywy maryjne. W celu przybliżenia czytelnikom dziejów z życia Maryi autor stworzył ciekawą, napisaną w przystępnej formie, wierszowaną opowieść o życiu Najświętszej Panny, w której odnajdujemy nawiązania do tradycji literatury staropolskiej (apokryfy, pasje, barokowy sposób obrazowania, pieśni maryjne, Matka Boska obdarowująca natchnieniem twórczym). W Wianuszku majowym arcybiskup stara się nie tylko odtworzyć życiorys swojej bohaterki, lecz także stworzyć Jej psychologiczny portret, próbując oddać słowami reakcje, uczu-

102 Z.Sz. Feliński, Nawotywanie narodu polskiego do wypetniania ślubów króla Jana Kazimierza i Stanów Rzeczypospolitej zaprzysiężonych imieniem narodu w Archikatedrze lwowskiej roku pańskiego 1656, [w:] Miesiąc maj z błogosławionym arcybiskupem Felińskim, oprac. T.A. Frącek RM, T.K. Komar RM, Warszawa 2003, s. 173. 
cia Maryi. Dodajmy też na zakończenie niniejszych rozważań, że tylko w tym jednym utworze Felińskiego Bogarodzica zostaje przedstawiona jako postać literacka. Motywy maryjne, takie jak: artysta tworzący obraz Matki Boskiej, lirnik głoszący Jej chwałę, kontemplacja rzeźby, których inspiracji należy poszukiwać w dorobku romantyków, nie odnoszą się już tak bezpośrednio do Rodzicielki Jezusa, jak wiersze z Wianuszka. Jednakże trudno zaprzeczyć, że są to niezwykle ciekawe pomysły w traktowaniu tematyki maryjnej, świadczące o pisarskich umiejętnościach autora. Bardzo oryginalnym motywem, istniejącym w lirykach Felińskiego, jest bez wątpienia pochwała miesiąca maja. Szczęsny wdzięcznie łączy tu bowiem uroki wiosny z treściami religijnymi. Ciekawie w dorobku literackim arcybiskupa przedstawia się także przypomnienie w Praksedzie starej, hagiograficznej legendy związanej z kultem Matki Boskiej Poczajowskiej, a kreacja Maryi jako Królowej Polski odzwierciedla głęboko zakorzenioną w świadomości pokoleń, dodającą otuchy w trudnych chwilach, pewność o Jej wielkiej przychylności dla nieustannie cierpiącego narodu.

\section{Marian themes in works of Zygmunt Szczęsny Feliński}

\section{Summary}

The purpose of this article is to present the Marian motifs appearing in works of Zygmunt Szczęsny Feliński (1822-1895) — son of exiled to Siberia mother, a student of mathematics in Moscow, archbishop of Warsaw, a patriot. On the basis of analysis of: Nowy wianuszek majowy z tajemnic życia Maryi przez arcybiskupa Szczęsnego Felińskiego na Jej cześć uwity, poems published in magazines (Prośba o natchnienie, Miesiąc maj, Tęcza), Oskar and Wanda and Prakseda, which content alludes to romantic poetic novel, the following ideas of Feliński are highlighted and discussed as follows: verse life of the Virgin Mary, the legend of the miraculous defense of Poczajów, painter creating his artistic work with the figure of Mary, pictures which operates in the ,,presented world" of the individual works with the image of the Virgin Mary, the symbolism of blessed flowers (lily, rose, violet), person playing the lyre proclaiming the honor of the Mother of God, Queen of Polish, prayer of heroes, the praise of the month of May combining an idyllic descriptions of nature with religious values and admiring the sculptures. This article describes creative output of Feliński dedicated to the Virgin Mary. It reveals personal piety of archbishop and emphasizes enormous contribution of the achievements of the author in the development of Marian issue in Polish literature. 